\title{
Approaching sustainable development practices and quality strategies in the Romanian dairy industry
}

\author{
Nicoleta Andreea NEACȘU \\ Transilvania University of Brașov, Brașov, Romania \\ andreea.neacsu@unitbv.ro,deea_neacsu@yahoo.com \\ Anca MADAR \\ Transilvania University of Brașov, Brașov, Romania \\ madaranca@gmail.com,ancamadar@unitbv.ro
}

\begin{abstract}
The Romanian dairy industry has experienced a significant evolution in the last 30 years. Improving product quality is a decisive and important factor for increasing competitiveness in both domestic and foreign markets. The concept of sustainability is increasingly found in the quality policies and objectives set by dairy producers. This paper aims to capture the current sustainable development practices and quality strategies applied by companies in the dairy sector in Romania and how they are perceived by consumers. In order to highlight the opinions and attitudes of Romanians regarding the quality strategies and sustainable development practices that are applied in the dairy sector, the authors conducted a quantitative marketing research among the Romanian population. The sampling method was non-random, and a questionnaire was used to collect the data, which was displayed on a web page (Computer Assisted Web Interviewing). The research revealed that many Romanians have heard of the concept of "sustainable development", but do not know very well what it refers to. The authors consider that the topic is up to date and that based on the results of this research, companies in the analyzed sector can improve their applied quality strategies and adopt new sustainable development practices in order to improve their products and increase consumer satisfaction.
\end{abstract}

Keywords: quality strategies, sustainability, dairy products, quantitative research, food waste, quality standards.

\section{Introduction}

The application of quality strategies and sustainable development practices is a decisive and important factor for increasing the companies' competitiveness in the market. The concept of sustainability involves increasing the corporate responsibility towards people and the environment. This can be achieved by adopting recommendations and actions for sustainable business development, in order to be able to leave a sustainable economic environment and a cleaner planet to future generations. Sustainability is a long-term process and involves the development of long-term strategies, with modern technologies playing an important role in this.

In order to identify the opinions and attitudes of Romanian consumers regarding the quality strategies used in the Romanian dairy industry, the authors conducted a quantitative marketing research, using the CAWI method as a data collection technique. The aim was also to find out if they know the term "sustainable development" and the sustainable development practices applied in this sector.

The research results indicate that Romanians have heard of the concept of "sustainable development", but most do not know what it refers to. Most respondents consider it important to have certifications on the dairy market, but at the same time, a large proportion of respondents are not familiar with ISO and HACCP standards and certifications. 


\section{Literature review}

At the level of the European Union, the production of dairy products increased, on average, in the period January-July 2020 compared to the period January-July 2019 by $1.85 \%$. The highest increase was recorded in the production of whole milk powder $(4.7 \%)$, followed by the whole milk (3.7\%), cheese and raw milk (2.0\%). Butter production increased by $1.6 \%$ over the same period (European Commission, 2020).

According to the "EU Agricultural Outlook for Markets and Income 2018-2030",

PICBE |

631 prepared by the European Commission, the consumption of dairy products at European level will register an increasing trend in the period 2018-2030 (with an increase of milk production by 900,000 tons milk per year). Consumption of cheese in particular will increase, while consumption of fresh milk will continue its downward trend (European Commission, 2018).

However, global demand for dairy products will increase over the next decade due to population growth (a visible phenomenon in Africa) and rising incomes. Thus, the European Union will continue to be a leader in the dairy export market, together with New Zealand. They will meet the specific requirements of consumers such as: organic products, products that are not genetically modified, local products, and the existence of quality and environmental management standards. In terms of imports, the main countries from which the European Union imports dairy products are: China and Russia (butter) and the United Kingdom and Japan (cheeses) (European Commission, 2018). Although global demand for dairy products will increase, the European Commission expects stable prices in the coming years.

Similar to the situation at the European level, the production of dairy products increased in Romania in 2019, compared to the previous year, by an average of $0.4 \%$ (4,887 tons). Whole milk production increased by $7.7 \%$, followed by sour milk production $(4.4 \%)$ and cheese production $(0.2 \%)$. Production decreased for the following dairy products: powdered milk $(-32.0 \%)$, melted cheese $(-2.3 \%)$, butter $(-2 \%)$ and cream $(-0.2 \%)$ (INS, 2020).

Quality management is a set of activities aimed at achieving certain objectives, through the optimal use of resources (Dragolea, 2020). It can satisfy two types of needs: those expressed by the customer and the implicit ones. In order to be considered effective and efficient, the quality management system must meet certain criteria and requirements. Its correct implementation determines a series of advantages both for the organization and for its clients. These are some of the most important principles of quality management: focus on customer needs and their satisfaction, continuous quality improvement, error prevention and employees accountability regarding quality.

The concept of sustainability involves increasing corporate responsibility towards people and the planet by adopting certain recommendations and actions for a sustainable business development, in order to be able to leave a sustainable economic environment and a cleaner planet to future generations. Sustainability is a long-term process and involves the development of long-term strategies, with modern technologies playing an important role. Investments in the future must begin as soon as possible, starting today, so that future generations can live in a natural and economic environment suitable for a qualitative human life.

According to Bizoza (2012) sustainable development is a model of economic growth in which the use of resources aims to meet human needs, while preserving the environment, so that these needs can be met not only now but for future generations. The same author argues that an effective institutional framework is needed for sustainable development at all levels.

The dairy industry is no exception to sustainable development, as many companies in this field have taken action towards implementing this. They have implemented various quality 
strategies which, in addition to the advantages related to product quality and process efficiency, have also brought benefits in terms of protecting the available resources and the natural environment. Such measures have been taken in the United States where investments have been made in technology and production assets (Von Keyserlingk et al., 2013; Høyer et al., 2019), in order to reduce energy and water consumption but also to reduce the impact of the resulting pollutants on the environment. In Canada, standards have been developed for the care of dairy cattle (Ritter et al., 2020), which take into account: milk quality, food safety, animal care, traceability, environmental sustainability and biosecurity. Tricarico et al. (2020) mentioned that attention must be focused on the environmental, economic and social issues in both high- and middle-income countries. The author points out that animal welfare and environmental impact are increasingly critical in high-income countries, while in low-income countries there are high rates of malnutrition in children, with long-term negative implications for health and the economy. He emphasizes that increasing sustainability is an opportunity for low-income countries to increase the amount of food for the vulnerable population groups, while reducing pressure on resources and environmental impact. Implementing sustainable development practices is an effective solution to counteract these negative effects (Neacsu, Madar, 2020).

The sustainability adoption at farm level (Balaine et al., 2020), translates into increasing agricultural yield using the same level of resources, or lower, in order to reduce the negative agriculture effects on the environment.

\section{Methodology}

The authors conducted a quantitative marketing research (opinion poll), to quantify the extent to which Romanian dairy consumers are familiar with the term "sustainable development" and to estimate their perception about the quality strategies used in this market. They wanted to identify whether respondents know how sustainable development practices are applied in this sector.

520 consumers of dairy products from Romania were interviewed. The main objective of the research was to determine the perception of the subjects regarding the use of quality strategies in this market and the application of sustainable development practices in this industry.

The specific objectives of this research were:

- Determining the opinions of dairy consumers regarding the quality strategies applied in this sector;

- Identifying the attitude of dairy consumers towards quality standards in this market;

- Identifying consumers' views and perceptions on sustainable development measures that have been implemented in the dairy market;

- Knowing consumers' opinions and perceptions about glass packaging for dairy products;

- Knowing consumers' opinions and perceptions on food waste in general and on waste of dairy products in particular;

- Identifying consumer views and perceptions on sustainability measures to be implemented in the dairy market.

The opinion polling technique was used, utilising the computer-assisted questionnaire (CAWI: Computer Assisted Web Interviewing) as a data collection tool. After collecting the information using the questionnaire, the processing of statistical data was done with the SPSS system (Statistical Package for Social Sciences) (Neacsu, Baltescu, Balasescu, Boscor, 2017).

Given the exploratory nature of the research, the aim was to obtain as many completed questionnaires as possible. The study was conducted on a sample of 520 consumers, structured as 
follows: 61\% women (respectively 317 people) and 39\% men (respectively 203 people). The age of the respondents is presented in Table 1. It is observed that the majority of respondents $(34.6 \%)$ are aged between 36 and 50 years, followed by those aged between 25 and 35 years $(27.3 \%)$ and $51-65$ years $(20.8 \%)$.

Table 1. Descriptive information of survey participants

\begin{tabular}{|ll|l|l|l|l|}
\hline & Frequency & Percent & Valid Percent & Cumulative Percent \\
\hline Valid & Under 25 years & 62 & 11.9 & 11.9 & 11.9 \\
& 25 - 35 years & 142 & 27.3 & 27.3 & 39.2 \\
36 - 50 years & 180 & 34.6 & 34.6 & 73.8 \\
51 - 65 years & 108 & 20.8 & 20.8 & 94.6 \\
Over 65 years & 28 & 5.4 & 5.4 & 100.0 \\
Total & 520 & 100.0 & 100.0 & \\
\hline
\end{tabular}

The study took place between September 2020 and October 2020. The data collection was carried out on the basis of a questionnaire containing 22 questions, of which 5 were demographic questions, and the other 17 were asking the subjects about the quality strategies and sustainability measures implemented in the dairy market.

\section{Results and discussions}

The results of the quantitative research can be divided into three broad categories.

1. Educating end-users on the importance of obtaining certifications in quality management, food safety, environmental safety, occupational safety and ecology dairy products.

Of the subjects surveyed, the majority $(54.42 \%)$ consider that the existence of food safety, quality management, health and occupational safety certifications is an important and very important factor. Only $30.95 \%$ consider it a little or no important factor (figure 1).

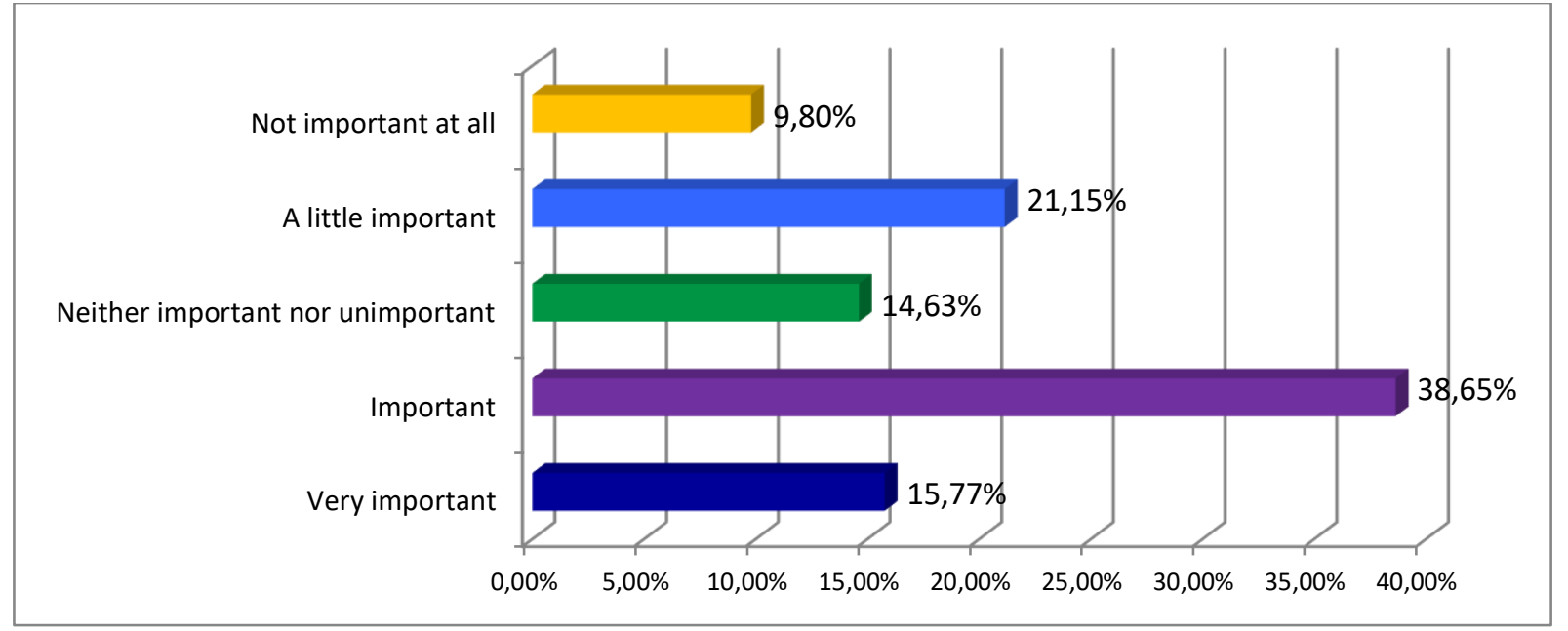

Figure 1. Respondents' opinion on the existence of certifications

Source: Own research of the authors. 
Among the respondents there is no predominant opinion regarding the existence of ECO certifications for dairy products present on the Romanian market. The vast majority of respondents are not familiar with ISO and HACCP standards and certifications (which are the most common and common certifications on the dairy market). Only $39.81 \%$ of respondents are familiar with the ISO 22000 standard, while the HACCP standard is known only by $24.27 \%$ of respondents. $58.3 \%$ of the respondents are not familiar with the ISO 9001 standard, and $80.6 \%$ of them do not know the OHSAS ISO 18001 certification.

Although dairy producers on the Romanian market have invested in the implementation of quality management systems, food safety, environment and occupational safety and in obtaining international certifications, our marketing research has shown that only some respondents are familiar with those standards. Although producers have focused on partnering with organic farms, consumers are unaware of the conditions for obtaining certification of an organic dairy product and do not know how to recognize a certified organic product. There is a reserved attitude towards ensuring that products are organic, with many consumers considering the addition of the term organic, eco, ecological or organic to be just a promotion strategy. In other words, they are not educated in understanding the information provided or in the conditions for certification of organic farms or in the benefits of organic products.

The solution could be to run information programs by major dairy producers. So far, only Friesland Campina's Napolact brand has run such a campaign on its website. The authors recommend that these campaigns should be carried out offline, in supermarkets, through discussions with buyers and the distribution of flyers, in order to reach consumers who are not using the companies' websites. These promotional campaigns can also be carried out on television and radio, where companies will be able to address a larger number of consumers. Although these programs involve some costs, the results may outweigh the costs. Under such programs, consumers can become aware of the importance of certifications and be open to testing organic products, which might have a positive impact on their health.

2. The use of glass packaging and the creation of collection spaces for such packaging

Currently, the large producers of dairy products on the Romanian market do not use glass packaging for their products, even if glass is a material that can be recycled indefinitely, by melting, without affecting its quality. Glass is also considered the best solution for health and taste, as it has absolutely no effect on the aroma of milk and there are no chemicals that could interact with the liquid, as it is the case with plastic or other packaging.

The research revealed that most of the respondents $(59.2 \%)$ are willing to pay extra (on average 0.50 Euro / product) for the packaging of the dairy product to be made from recycled or recyclable materials. Over $70 \%$ of respondents $(73.8 \%)$ consider the recycling of dairy products packaging after use to be important and very important.

Most respondents (61.54\%) heard about the concept of "sustainable development", but most of them $(68.75 \%)$ do not know this concept.

The majority of respondents $(64.81 \%)$ consider it important and very important that the packaging of dairy products should be made from recycled materials, while only $13.08 \%$ do not consider this aspect at all important and $6.73 \%$ consider this aspect to be unimportant (figure 2). 


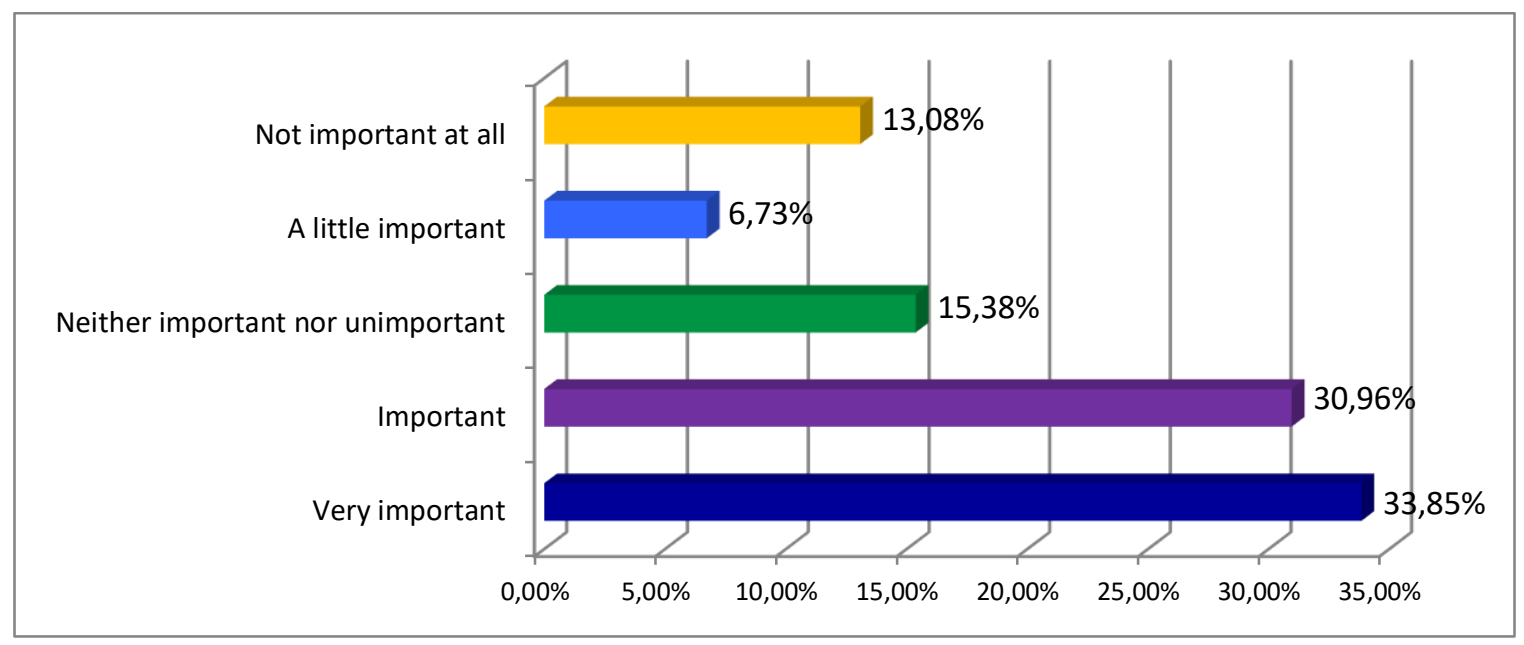

Figure 2. Respondents' opinion on the importance of dairy packaging being made from recycled materials

Source: Own research of the authors.

Following the market research carried out, it was observed that the respondents consider that in their purchase it is important, but not a priority, that the packaging should be made of recyclable materials. Thus, the authors' proposal for producers is to use glass packaging for most dairy products, such as milk, yoghurt, cream, sana, kefir and create collection facilities for recycling. These products sold in glass packaging will have a higher price, but the price difference will be recovered by recycling the packaging in specially designed collection centers. We know that this proposal involves quite high costs, but this packaging will make an important contribution to sustainable development and product quality.

3. Reduction the waste of dairy products

It is known that food waste is a global problem. The importance of this issue has grown considerably in recent years and will continue to grow due to the need to feed a growing world population. Globally, it has been identified that around one third of the food produced for human consumption is wasted or lost, generating significant economic and environmental costs (European Commission, 2020). Food is vital, a precious commodity, and its production requires significant resources.

Even if new processes and techniques have been introduced at the moment to extend the shelf life of dairy products (UHT, good bacteria), unfortunately their waste has not decreased enough. Further techniques and research in this direction are needed to make the fight against dairy waste more efficient.

To remove this waste, dairy companies together with large traders could reach an agreement and reduce the price of dairy products that are about to expire soon. This method is already applied to certain products (fruits, vegetables, meat) and could be extended to dairy products. This proposal does not involve high costs, it is only necessary to inform consumers about this option.

Starting from the results of the marketing research and the information collected about the companies on the dairy market in Romania, the authors identified several quality strategies that are applied in this sector. 
The strategy of quality domination requires maintaining a market or market segment that requires a high level of efficiency and a high volume of sales. It focuses on selling high quality products and in high volumes. In order to keep their place in the market, the large dairy companies in Romania have to make the manufacturing processes more flexible and come up with new or improved products. The most eloquent example for the application of this strategy on the dairy market is the emergence of organic products. In Romania, the market for organic dairy products is constantly growing. The assortments of organic products are from different subcategories such as: milk, plain yogurt, fruit yogurt, butter, telemea, as well as others. The most visible brands on the store shelves with such products are: Napolact, Olympus, LaDorna, Zuzu and Covalact. Organic products have been successful because the Romanian consumer has a higher interest in sustainability than it used to have in previous years, which has also been seen in the results of the market research. This market segment is a challenge for producers because even though it is growing, the consumer segment is still small and the price, compared to conventional products, is high.

The strategy of differentiation by quality is based on the knowledge of the quality characteristics of the products or services in terms of manifestations and level of achievement, such as reliability, maintainability, availability, accessibility. This strategy is applied by all the top competitors on the Romanian dairy market. They all produce products of the same type, but which are differentiated by certain qualitative characteristics.

Consumption of dairy products is a global source of food waste due to the high level of movement of goods, supply and short shelf life of the products. For a more sustainable future, dairy farmers have introduced the UHT milk, which has a longer shelf life. Products with a naturally extended shelf life have also been made with the help of lactic cultures (good bacteria), which can delay the deterioration of the product. These products have been successful among consumers eager for clean labels (organic products), avoiding food waste and the possibility of savings.

The strategy of diversification through quality offers companies the possibility to capitalize on the research and development potential and the different technologies available, through which new markets are conquered and superior quality classes are offered in relation to the competition. Diversification is done by adding new product features or by adding new products to the market. The strategy of quality diversification is carried out by most of the top producers on the dairy market. We can see that the Albalact Company has resorted to this strategy by launching a range of Zuzu Dolce desserts, Fulga puddings, Zuzu squeezed yogurt and Frupt natural fruit juices. The other competitors completed this diversification by adding other new products. For example, Danone has launched the Danone Delicious range of yoghurts that contain fruit and biscuit yogurt, the Danette dessert range and Cremosso yoghurts. Last but not least, Hochland used this strategy when it expanded and diversified its range of cheeses, by adding Grönländer matured cheese, the Atelier artisanal range, Almette cheese creams, Hochland Crème, and the Hot Delights range, which contains grilled camembert, mozzarella, breaded cheese and grated cheese for pizza. This strategy has allowed these companies to maintain their market as well as their place in this market, but at the same time to enter new market segments and eliminate competitive pressure.

This strategy can be seen in dairy companies that have paid special attention to consumer needs and requirements. This strategy was used by: introducing organic products on the market by Albalact, Danone, Brașov Dairy (Olympus), FrieslandCampina Romania (Napolact), introducing natural juices (Albalact), introducing the range of desserts (Albalact), introducing yogurts with fruit (Danone), introducing a the range of vegetable drinks (Brașov Milk Factory), 
introducing a the range of goat milk products (Brașov Milk Factory), introducing the artisanal range (Hochland Romania), introducing innovative products (squeezed yogurt - Albalact, hot cheeses and cream cheese - Hochland Romania) and by diversifying packaging (both in terms of size, shape and material).

The strategy of searching for a style through quality is a new strategy outlined in the literature, which involves increasing the aesthetic appeal of the product (e.g. new products unchanged in terms of features or functionality, but which come with new models or colors). The purpose of this strategy is for the company to acquire and shape its own identity and to approach a certain part of the market. Thus, the Albalact company stood out and shaped a place on the Romanian dairy market by selling Zuzu milk using a new concept for packaging: plastic cans. These cans with different colors and weights are to the liking of consumers due to the ease of transport and use, more precisely due to the handle they have. Another strategy was to market this product in the $500 \mathrm{ml}$ version, the smallest packaging on the market. This campaign to reinvent the packaging had the slogan "Milk first".

\section{Conclusion}

The dairy market has undergone a significant evolution in the last 30 years, moving from collectivization and state production, to privatization, foreign investment and the modernization of the necessary processes and equipment. At the same time, the market is strictly regulated at European and national level, in order to ensure product quality and safety. Quality management on the dairy market is present through the implementation of quality management systems, food safety, environment and occupational safety, obtaining international certificates and implementing its own procedures, specifications and rules in all stages of the product preparation. The concept of sustainability is increasingly found in the quality policies and objectives set by dairy producers. This is manifested by the care given to animal welfare, bioethics, organic dairy production, process optimization and resource consumption and packaging innovation.

The companies are in continuous development, as are the requirements of the population regarding the goods and services made available. That's why offers are becoming ever more diversified and more individualized to cope with the trends in demands (Balasescu, Balasescu, 2019). Improving product quality is the most decisive and important factor in increasing product efficiency. This is essential in terms of competitiveness in both internal and external markets. By implementing quality strategies, the company's management aims to: meet the requirements of beneficiaries, meet social needs and set the level of quality according to the market requirements.

Among the quality strategies applied by the most important dairy companies in Romania, we distinguish:

- The strategy of domination by quality (organic products, specific cheeses, fitness products);

- The strategy of differentiation by quality (organic products, UHT milk, drinking milk with 1 , $7 \%$ and $3.7 \%$ fat);

- The strategy of diversification by quality (natural juices, matured cheese, tea, yogurt with specific fruit);

- The strategy of looking for a style by quality (canned packaging, cereal yogurt, new logo).

In conclusion, based on the results of the paper, the authors recommend companies operating in the dairy sector, but also central and local authorities to invest more in educating the population about the concept of sustainable development, sustainable development practices and reducing food waste.

The main limitation of the research is the sample size, which means that its results are not extrapolated to the entire research population. However, the authors consider that the paper has 
academic contributions in this field and it should be the starting point for future research on this topic.

\section{References}

Balainea, L., Dillonb, E. J., Lapplea, D., Lynch, J. (2020). Can technology help achieve sustainable intensification? Evidence from milk recording on Irish dairy farms. Land Use Policy, vol. 92, 1-12.

Balasescu, M., Balasescu, S. (2019). Ways to create an effecte positioning of Romanian universities through identity, image and promotion elements. Proceedings of the $13^{\text {th }}$ International Conference on Business Excellence 2019, 13(1), 47-55.

Bizoza, A. R. (2012). United Nations Conference on Sustainable Development, (RIO+20), National Preparatory Process for Rwanda, [online] Available at: <https://sustainable development.un.org/content/documents/1030rwanda.pdf> [Accessed on 19.11.2020].

Dragolea, L.L. (2006). Managementul calității - funcții și principii. Annales Universitatis Apulensis Series Oeconomica, 2006; 8(3)1-7, [online] Available at: <http://www. oeconomica.uab.ro/upload/lucrari/820063/32.pdf > [Accessed on 19.11.2020].

European Commission. (2018). EU agriculturaloutlook 2018-2030: Growing export demand for dairy products as world population, [online] Available at: <https://ec.europa.eu/info/ news/eu-agricultural-outlook-2018-2030-growing-export-demand-dairy-products-worldpopulation-expands-2018-dec-07_en> [Accessed on 20.11.2020].

European Commission. (2020). Shorttermoutlook for EU agricultural markets in 2020 [online] Available at: <https://ec.europa.eu/info/sites/info/files/food-farming-fisheries/farming/ documents/short-term-outlook-autumn-2020_en.pdf> [Accessed on 20.11.2020].

European Commission. (2020). Milk market situation, [online] Available at: <https:/ec.europa.eu/info/sites/info/files/food-farming-fisheries/farming/presentations/ milk-market-situation-slides_en.pdf > [Accessed on 19.11.2020].

Høyer, M. R., Oluyisola, O.E., Strandhagen, J. O., Semini, M. G. (2019). Exploring the challenges with applying tracking and tracing technology in the dairy industry. International Federation of Automatic Control, 52(13), 1727-1732.

INS - National Institute of Statistics. (2020). Producţia de carne, lapte şi produse lactate din unităţile industriale în anul 2019, [online] Available at: <https://insse.ro/cms/sites/ default/files/com_presa/com_pdf/prod_carne_lapte19r_0.pdf > [Accessed on 19.11.2020].

Neacsu, N.A., Madar, A. (2020). Tourists' vision about the implementation of sustainable development practices in the hospitality industry in Romania. Proceedings of the 14th International Conference on Business Excellence 2020, Volume: 14, Issue: 1, 769-779.

Neacsu, N.A., Baltescu, C., Balasescu, S., Boscor, D. (2017). The influence of design and aesthetics elements in choosing clothing, Industria Textila, no. 5, 375-379.

Ritter, C., Mills, K. E., Weary, D. M., Von Keyserlingk, M. A. G. (2020). Perspectives of western Canadian dairy farmers on the future of farming. Journal of Dairy Science, 103(11), 10273-10282.

Tricarico, J. M., Kebreab, E., Wattiaux, M. A. (2020). MILK Symposium review: Sustainability of dairy production and consumption in low-income countries with emphasis on productivity and environmental impact. Journal of Dairy Science, 103(11), 9791-9802.

Von Keyserlingk, M. A. G., Martin, N. P., Kebreab, E., Knowlton, K. F., Grant, R. J., Stephenson, M., Sniffen, C. J., Harner, J. P., Wright, A. D., Smith, S. I. (2013). Sustainability of the US dairy industry. Journal of Dairy Science, 96(9), 5405-5425. 